\title{
The Value of Project Management Education for IT Professionals
}

\author{
Angela Lecomber ${ }^{1}$ and Arthur Tatnall ${ }^{2}$ \\ ${ }^{1}$ See Differently Consulting and RMIT University, ${ }^{2}$ Victoria University, Australia \\ angela@seedifferently.com.au, Arthur.Tatnall@vu.edu.au
}

\begin{abstract}
IT organisations and organisations with IT departments frequently procure project management training as part of their initiatives to improve business outcomes through professional education. This paper utilises the results of a research study that focused on the training of the project management methodology PRINCE2 in an organisation where IT was one of the departments. The longitudinal study over two and a half years reported on the adoption of the PRINCE2 project management methodology by sixteen employees following the successful completion of a PRINCE2 training course. Two different outcomes were observed: some individuals continued to develop their interest in PRINCE2 and looked for a stable network that will support their practice, even if they resigned from the organisation. The other outcome was that other individuals ceased using PRINCE2 for their projects if there was no imperative given by the organisation to use it and no example set by others in using it. The adoption outcomes from this study have implications as to the interventions that need to be implemented by organisations to derive the value from an investment in professional vocational education in project management for all relevant professionals.
\end{abstract}

Keywords: Project Management Training • IT Professionals • PRINCE2 • Professional Vocational Education · Actor-Network Theory

\section{Introduction}

In this paper we will argue that an important part of the education of IT professionals should relate to project management. Apart from the normal material relating to the disciplines of computing, IT professionals need to know about how IT systems can best be developed. They need to know how to go about designing a system, but also how to build and implement a system. They need to have a good knowledge of project management and this topic should be an important part of any professional education in IT. Many IT projects in recent years have resulted in failure [1] and so knowledge of the appropriate application of project management skills is vital for Information Systems professionals.

As project management evolves as a field of practice, companies are now realising that their entire business, including most of the routine activities, can be regarded as a series of projects. The Business Directory [2] defines a project as a: "Planned set of interrelated tasks to be executed over a fixed period and within certain cost and other limitations". Simply stated, we are managing our business by projects [3], and this is even more so in the development of information systems. 
To improve the management of projects, project management methodologies are regularly employed with the aim of increasing project efficiency and effectiveness [4]. Public and private sector organisations invest significant resources into efforts, ranging from a review and tailoring of the current practices to the adoption or development of new project management methodologies [5].

Nonetheless, project professionals are trusted to deliver projects even if they are not accredited [6]. The Price Waterhouse Coopers [5] report stated that only 20\% of professionals were certified in their organisation's preferred methodology. Why is this? Could this be due to the lack of connection between the theory of project management and its practice? There appears to be a gap between what education providers are offering and what is needed to deal with projects in today's work environment [7].

\section{The Value of Professional Education in Project Management}

The teaching and learning of project management have attracted the attention of many scholars within project management professional training [8]. This is especially true in the case of IT projects.

Since the Australian Computer Society (ACS) included IT Project Management in its Body of Knowledge for Computer Professionals [9, 10] most Australian universities now include one of more IT Project Management subjects in both undergraduate and postgraduate degrees. In most cases this involved practical work using software packages such as Microsoft Project to formalise these concepts. As well as IT project management education in universities, however, there is also substantial industry professional training in project management and it is this that this paper addresses.

In the $21^{\text {st }}$ century, project management education and training is often still confined to the instructional approaches of the $20^{\text {th }}$ century and focused on technical instrumentality [11-14]. That current approaches of educating and training project management professionals do not meet the need of modern enterprises is now well accepted [7]. In fact, Starkweather and Stevenson [15] found that there was no difference in project success rates between PMP (Project Management Professional) certified project managers and uncertified project managers. Both Starkweather and Stevenson [15] and Crawford [16] found that there was little or no empirical evidence that certified project managers making use of the popular methods of project management education are more successful than non-certified project managers.

Joslin and Muller [17] found that there was a positive relationship between the use of project management methodologies by project management practitioners and project success. Methodologies included both $\mathrm{PMBoK}^{1}$ and PRINCE2 which are described as project management 'best practices' by the respective 'owners' which are the Project Management Institute (PMI) and AXELOS ${ }^{2}$ respectively.

\footnotetext{
PMBoK is not a methodology but a Body of Knowledge.
}

2 AXELOS was set up in 2014 by as a joint venture between the UK Government and Capita with the aim of developing, managing and operating qualifications in best practice. It is used in methodologies formerly owned by the Office of Government Commerce. 
Winter et al. [18] reported that practitioners found that mainstream methods and techniques could be a useful source of guidance for certain aspects, but they provided no guidance on 'how' to navigate the complexity of projects in the ever-changing flux of events.

At the heart of challenges faced by the discourse on project management education and training is the assumption that project management outcomes can successfully be predicted as a simple cause and effect relationship which imply a rigid utilisation of project management methodologies and a rigid control and measurement of outputs, and in effect an instrumental ideology [19].

Ojiako et al. [8] in their research on how engineering students perceive their learning experiences of project management found that the focus for learning should be on the student as a manager rather than a 'technician'. In such a role as manager, engineers would be expected to "grasp the complexity and fluidity associated with the range of interconnected social, technical, political, and economic factors that commonly matter within work packages and projects” [8 :57]. These findings are quite unsurprising. What is important is to introduce engineering students, and also IT students, to the complexities associated with projects. However there is a difficulty in achieving this due to the educational delivery of courses being narrowly compartmentalised and linked rigidly to learning outcomes [8].

\section{PRINCE2 Project Management Methodology}

PRojects IN Controlled Environments Version 2 (PRINCE2) is a methodology for managing projects and has grown to become a de facto 'standard' as a project management method in more than 150 countries worldwide [20, 21]. PRINCE2 is a methodology (as opposed to a body of knowledge such as PMBOK) that was developed for the UK Government to manage their IT projects and was based on softsystems methodology [20-23]. The first version of PRINCE was published in 1989 $[20,21]$.

A multi-disciplinary research team from the Queensland University of Technology (QUT), financed by the former owners of the intellectual property of PRINCE2, the Office of Government and Commerce (OGC), undertook one of the first empirical studies into the impact of the PRINCE2 methodology on project performance [21]. The research study was entitled 'Creating Value in Project Management using PRINCE2' and also conducted parallel research on the impact of other unspecified (non-PRINCE2) contemporary project management methodologies.

The researchers interviewed PRINCE2 practitioners from a diverse range of industries (including Information and Communications Technology, Construction, and Transport) and across three major geographical regions (United Kingdom and Europe, United States and Australia) [21]. The researchers found that PRINCE2 was perceived as a very robust, comprehensive and pragmatic project management framework [21].

Problems and issues which impeded the adoption of PRINCE2 to projects were organisational and not methodological, and the dominant issue identified by participants was poor project sponsor/board performance and a reflection that organisations either do not know how, or do not possess the commitment to properly 
implement PRINCE2 [21]. This finding was supported by the research study reported in this paper.

Wells [4] explored the effectiveness in the workplace of project management methodologies including PRINCE2. Her research found that there was "a chasm between the intended strategic directions of the project management methodology and its actual contribution to projects, managers and their teams" [4]. According to Wells [4] the purported benefits are often not realised or can have unintended consequences at the project level and adversely affect project success.

Furthermore, Wells' [4] research on project management methodologies showed that the methodologies were useful for those that were at opposite ends of experience and accountability for projects:

- the inexperienced in project management, and

- those who were most senior in the organisation who were focused on the governance of projects.

In between these two ends of the spectrum, the "perceived benefits and advantages of using project management methodologies dramatically falls, to a minimum, corresponding to the middle ground of the range of perspectives" [4] the drop largely due to the drawbacks and limitations that the practitioners experienced in adopting the methodologies [4]. In other words, those who had some experience of project management considered the use of a project management methodology to be an overhead in their day to day work and did not use it. It was only useful for those who were inexperienced as it was a useful guide for them. It was also valuable for those who very experienced who were also senior managers as they were looking for ways to control projects and implement governance across the organisation by seeking a standard in delivering projects [4].

\section{Research Study - Longitudinal Case Study}

A research study was conducted by Lecomber [24] to understand how participants used and adopted the PRINCE2 methodology to workplace projects following a professional training course. The study, over two and a half years, used Case Study [25] as a method and consisted of both a questionnaire and focus group interviews. The research formulated qualitative answers to the main research question: 'How are practitioners influenced to apply project management 'best practice' (PRINCE2 in this study) in complex and dynamic environments?'

The study workplace consisted of a number of departments, one of which was an IT department. Two IT staff participated in the professional training program which consisted of sixteen staff drawn from the various departments across the organisation. Participants were questioned on what they thought of the training itself, how relevant it was to their own work and whether it would make a difference to their work in the future. The results showed that there were some participants who adopted as much of the PRINCE2 methodology as they were able for their work projects, and actively sought to improve their practice. Another group of participants had knowledge of the methodology but considered the overhead in using it far outweighed the benefit derived from using it. 
To analyse these two different forms of adoption, Innovation Translation, informed by Actor-Network Theory (ANT) was used. ANT enables the researcher to think in terms of different translations (or adaptations) and to seek to identify the actors involved and the interactions that formed possible stable networks supporting those translations [26]. Innovation Translation has the advantage of being able to explain examples of partial adoption, and of situations where what is actually adopted differs from what was proposed [27]. This was particularly relevant for this study as it could be said that one group of participants made only a partial adoption.

ANT, also known as the sociology of translation [28, 29], was developed by science and technology scholars Michel Callon and Bruno Latour, sociologist John Law and others. It is a conceptual framework for exploring collective socio-technical processes and aims to follow the actors in a given network in the process of new network formation [29]. Innovation Translation, informed by ANT, argues that an innovation moves along as a chain of consequence by energy given to it by everyone in the chain whose actions shape the innovation to suit themselves [27].

Actors in this case include the trainer, trainee (learner), curriculum and the workplace. According to Blomquist et al. [11], a practice approach on project management requires the study of action, activities and actors within projects. There are actors at play even before Day 1 of the training course. These are AXELOS, the Examination Institute (APMG) and the Accredited Training Organisation (ATO). The ATO provides the training material and the trainer. The ATO obtains the PRINCE2 manual from a bookseller who procures this from AXELOS, whilst APMG dispatches the exam paper. The nature of the outcome of the training experience is a result of the interaction of the human actors (the trainer and the other participants) and non-human actors (training materials, timetable, exam papers, PRINCE2 manual and training venue). After the training, the participant project manager seeks then to adopt the innovation in the workplace. This research study seeks to understand both the interactions that occur during training as well as in the workplace after the training course with respect to the adoption of the PRINCE2 methodology.

Callon [28] defines four moments (stages) of Innovation Translation: problematisation, interessement, enrolment and mobilization. The four stages, if successful, lock the actors into the network and create a stable translation [30]. This research looked at adoption in the form of two different translations:

5. Some participants adopted as much of the PRINCE2 methodology as they were able for their projects and actively sought to improve practice. The study named this adoption as the Performing Translation (PT). Those who had adopted PT had a focus on continuous improvement in their practice. Those who adopt the PT are people who keep attempting to apply their learning and hence learn more. In addition, those who adopted the PT conducted their own research into 'best practice' outside of work hours.

6. The other group of participants who had knowledge of the methodology but considered the overhead in using it far outweighed the benefit derived from using it formed the Knowing Translation (KT). A KT sees nothing in the formal structures of PRINCE2 that is so valuable that they would sacrifice early delivery by going through procedures stated in the methodology. Those 
who had adopted the KT would only apply what they had learned to the workplace if they perceived adoption across the organisation.

In the case of PT participants, as their organisation did not have the supports such as strong leadership for using a methodology and a strong Project Management Office (PMO), some participants who adopted the PT eventually resigned from the organisation. In this research study, the PMO was weak and could not enforce the governance needed to support the use of PRINCE2.

Participants whose form of adoption was the Knowing Translation (KT) had knowledge of the Project Management methodology but considered the overhead in using it far outweighed the benefit derived. The lack of support from the top-down commencing with the Senior Leadership team and the original sponsor of the methodology had a strong influence on those who adopted the KT. A senior leadership team and sponsor must go beyond paying 'lip-service' to the methodology and actively comply with the methodology in terms of behaviours, responsibilities and expectations of their role on the project as sponsors and Project Board members.

\section{Implications}

The research results by Lecomber [24] thus identifying two adoption outcomes as a result of project management training could be used to assist organisations in their strategies to support embedding of learning outcomes following project management training. These results are congruent with the research conducted by the Sargeant et al. [21] study which showed that problems and issues which impeded the adoption of PRINCE2 to projects were organisational rather than methodological.

The value of professional vocational education and training in project management depended on what structures were in place in the organisation to support the adoption of the project management methodology.

These supports include:

- A strong Project Management Office (PMO)

- Senior leadership team that supports the use of the methodology

- Strong visible support by the sponsor of the methodology.

These issues have significant implications for the success of any project management training. It the training is not seen, by the participants, as relevant to their workplace and if appropriate organisational support is lacking then there is more likelihood that the training participants will become Knowing (KT) rather than Performing (PT).

\section{Conclusion}

IT professionals (and others) need to know how to go about designing a system, but also how to build and implement such a system and so should have a good knowledge of project management. For some, this is obtained in their university degree but for others it comes later, as a result of professional and vocational education. Given that in recent years many IT projects have resulted in failure, knowledge of the 
appropriate application of project management skills is a vital skill for all Information Systems professionals.

In this study, the emergence of two possible adoption outcomes has implications on how organisations derive value from their investment in professional project management education and training. As well as ensuring that the project management training is performed well, it is important that organisations commit to supports in place such as a strong PMO, senior leadership supporting the methodology and strong visible support from the sponsor if the organisation wishes to derive the value from the project management training otherwise the investment in training is a 'waste of money'. This is particularly important in the education of IT professionals.

\section{References}

1. Standish Group, CHAOS Report 2016: Outline. 2016, Standish Group: Boston, Massachusetts

2. Business Directory. Project. 2017 February, 2017]; Available from: http://www.businessdictionary.com/definition/project.html.

3. Kerzner, H., Project Management Best Practices: achieving global excellence. 2014, New Jersey: John Wiley and Sons.

4. Wells, H., How Effective are Project Management Methodologies? An Explorative Evaluation of their Benefits in Practice. Project Management Journal, 2012. 43(6).

5. Price Waterhouse Coopers. Fourth Portfolio and Programme Management Survey. 2014 [cited 2017; Available from: http://www.pwc.com/gx/en/services/advisory/consulting/portfolio-programmemanagement/global-ppm-survey-2014.html.

6. Konstantinou, E., Professionalism in Project Management: Redefining the Role of the Project Practitioner. Project Management Journal, 2015. 46(2).

7. Ramazani, J. and G. Jergeas, Project managers and the journey from good to great: The benefits of investment in project management training and education. International Journal of Project Management, 2015. 33(1): p. 41-52.

8. Ojiako, U., et al., Project Management Learning: A comparative study between engineering students' experiences in South Africa and the United Kingdom. Project Management Journal, 2015. 46(4).

9. Tatnall, A. and G. Reyes, Teaching IT Project Management to Postgraduate Business Students: a Practical Approach. Journal of Information Technology Education, 2005. 4: p. 153-166.

10. Burgess, S., Curriculum Planning for Information Management, in Business Information Technology. 1993, Royal Melbourne Institute of Technology: Melbourne.

11. Blomquist, T., et al., Project-as-practice: In search of project management research that matters. Project Management Journal, 2010. 41(1): p. 5-16.

12. Ojiako, U., et al., The criticality of transferable skills development and virtual learning environments used in the teaching of project management. Project Management Journal, 2011. 42(4): p. 76-86.

13. Skulmoski, G. and F. Harman, Information systems project manager soft competencies: A project-phase investigation. Project Management Journal, 2010. 41(1): p. 61-77.

14. Thomas, J. and T. Mengel, Preparing project managers to deal with complexity Advanced project management education. International Journal of Project Management, 2008. 26(3): p. 304-315.

15. Starkweather, J.A. and D.H. Stevenson, $P M P ®$ Certification as a Core Competency: Necessary But Not Sufficient. . Project Management Journal, 2011. 42(1): p. 31-41. 
16. Crawford, L., Senior management perceptions for project management competence. International Journal of Project Management, 2005. 23: p. 7-16.

17. Joslin, R. and R. Muller, Relationships between a project management methodology and project success in different project governance contexts. International Journal of Project Management, 2015. 33(1337-1392).

18. Winter, M., et al., Directions for future research in project management: The main findings of a UK government funded research network. International Journal of Project Management, 2006. 28(8).

19. Ojiako, U., et al., Project management learning: Key dimensions and saliency from student experience. International Journal of Project Management, 2014. 32(8): p. 14451458.

20. AXELOS. AXELOS Global Best Practice. 2015 [cited 2016; Available from: https://www.axelos.com/.

21. Sargeant, R., et al. Creating value in project management using PRINCE2. Office of Government Commerce, London, UK. 2010 [cited 2017; Available from: http://eprints.qut.edu.au/52853/.

22. Checkland, P. and J. Scholes, Soft Systems Methodology in Action. 1991, Chichester: Wiley.

23. Finegan, A., Soft Systems Methodology: an Alternative Approach to Knowledge Elicitation in Complex and Poorly Defined Systems. 1994, RMIT Centre for Remote Sensing and Land Information: http://www.csu.edu.au/ci/vol1/Andrew.Finegan/paper.html, 15 Nov 1998.

24. Lecomber, A., Reshaping the project manager's project story: An adoption study of 'best practice' project management, in Information Systems. 2017, RMIT: Under examination.

25. Yin, R.K., Case Study Research, Design and Methods. 5th edition ed. 2014, Thousand Oaks, California: Sage Publications.

26. Davey, W. and A. Adamopoulos, Grounded Theory and Actor-Network Theory: A Case Study. 2016. 8(1).

27. Tatnall, A., Innovation Translation as a Research Approach to Theorising Information Systems Implementation. International Journal of Networking and Virtual Organisations, 2009. 6(1): p. 64-76.

28. Callon, M., Some Elements of a Sociology of Translation: Domestication of the Scallops and the Fishermen of St Brieuc Bay, in Power, Action \& Belief. A New Sociology of Knowledge?, J. Law, Editor. 1986, Routledge \& Kegan Paul: London. p. 196-229.

29. Latour, B., Reassembling the Social: An Introduction to Actor-network Theory. 2005, Oxford, UK: Oxford University Press.

30. Davey, W., ANT, Phenomenography and a Research Question in Information Systems. International Journal of Actor-Network Theory and Technological Innovation, 2014. 6(2): p. 1-9. 